University of Nebraska - Lincoln

DigitalCommons@University of Nebraska - Lincoln

$1-1-1999$

\title{
RUNOFF AND EROSION FROM INTERRILL AREAS AS AFFECTED BY THE APPLICATION OF MANURE
}

John E. Gilley

ASAE Member Engineer, john.gilley@ars.usda.gov

Bahman Eghball

University of Nebraska-Lincoln

Jurg M. Blumenthal

Panhandle Research and Extension Center, Scottsbluff, Nebr.

David D. Baltensperger

University of Nebraska. Panhandle Research and Extension Center, dbaltensperger@tamu.edu

Follow this and additional works at: https://digitalcommons.unl.edu/usdaarsfacpub

Part of the Agricultural Science Commons

Gilley, John E.; Eghball, Bahman; Blumenthal, Jurg M.; and Baltensperger, David D., "RUNOFF AND EROSION FROM INTERRILL AREAS AS AFFECTED BY THE APPLICATION OF MANURE" (1999). Publications from USDA-ARS / UNL Faculty. 156.

https://digitalcommons.unl.edu/usdaarsfacpub/156

This Article is brought to you for free and open access by the U.S. Department of Agriculture: Agricultural Research Service, Lincoln, Nebraska at DigitalCommons@University of Nebraska - Lincoln. It has been accepted for inclusion in Publications from USDA-ARS / UNL Faculty by an authorized administrator of DigitalCommons@University of Nebraska - Lincoln. 


\title{
RUNOFF AND EROSION FROM INTERRILL AREAS AS AfFeCTED By THE APPLICATION OF MANURE
}

\author{
J. E. Gilley, B. Eghball, J. M. Blumenthal, D. D. Baltensperger
}

\begin{abstract}
This study was conducted to measure runoff and erosion from interrill areas as affected by the long-term application of manure and fertilizer to a Tripp sandy loam soil located near Mitchell, Nebraska. Soil which had been removed from the top $0.1 \mathrm{~m}$ of the soil profile was placed in a $1 \mathrm{~m}^{2}$ soil pan. Rainfall was then applied to the soil pan during initial and wet simulation events. Total runoff was similar on the manure and no-manure treatments. The long-term application of manure (55 years) at a rate of $27 \mathrm{Mg} \mathrm{ha}^{-1}$ (wet basis) per year did not significantly influence interrill erosion on this sandy loam soil. Interrill erosion was also unaffected by the addition of manure immediately before the rainfall simulation tests to soils on which manure had been applied in previous years. No significant differences in runoff and erosion were found among plots receiving varying amounts of fertilizer. Selected soil properties and erodibility factors were generally unaffected by the varying manure and fertilizer treatments.
\end{abstract}

Keywords. Fertilizer application, Interrill erodibility, Interrill erosion, Manure application, Runoff, Soil loss.

$\mathrm{M}$ anure is an excellent source of nutrients that can serve as a substitute for synthetic fertilizers. Organic matter contained in manure can improve the chemical and physical properties of soils low in organic matter. Manure can be utilized to achieve an optimum level of agronomic production while conserving natural resources.

A laboratory study to measure runoff and erosion from small plots on which liquid swine manure had been applied was conducted by Mitchell and Gunther (1976). Reduced rates of runoff and erosion resulted from the stabilizing effect of the liquid manure on the soil surface. A laboratory study measuring erosion from soils on which cattle manure had been applied was conducted by Chandra and De (1982). Following a 30-day incubation period, soils where manure was incorporated had reduced rates of erosion. Mueller et al. (1984) measured soil and water losses from small corn (Zea mays L.) plots on which dairy manure had been added. Reduced soil losses resulted from the application of manure.

A rainfall simulator was used by Giddens and Barnett (1980) to investigate runoff and soil loss as affected by the application of poultry litter. Litter application on fallow soil substantially reduced runoff and soil loss.

Article was submitted for publication in November 1998; reviewed and approved for publication by the Soil \& Water Division of ASAE in May 1999

This article is a contribution from USDA-ARS in cooperation with the Agricultural Research Division, University of Nebraska, Lincoln, and is published as Journal Series No 12,447.

The authors are John E. Gilley, ASAE Member Engineer, Agricultural Engineer, USDA-ARS, and Bahman Eghball, Assistant Professor, Department of Agronomy, University of Nebraska, Lincoln, Nebr.; and Jürg M. Blumenthal, Assistant Professor, and David D. Baltensperger, Professor, Panhandle Research and Extension Center, Scottsbluff, Nebr. Corresponding author: John E. Gilley, USDA-ARS, University of Nebraska, L. W. Chase Hall, Room 251, Lincoln, NE 68583-0934; voice: (402) 472-2975; fax: (402) 472-6338; e-mail: jgilley1@unl.edu.
Westerman et al. (1983) measured erosion from laboratory test plots on which poultry manure had been added. Manure characteristics, loading rates, incorporation, and the time between application and the first rainfall were all found to influence erosion rates. The objectives of this study were to:

- Determine the effects of the long-term application of manure and fertilizer on runoff and erosion.

- Measure runoff and erosion as affected by the timing of the most recent manure application.

- Identify the effects of the long-term application of manure and fertilizer on soil properties used to estimate soil erodibility factors.

- Calculate soil erodibility factors resulting from the long-term application of manure and fertilizer.

\section{SOIL EROSION MODELS}

The Revised Universal Soil Equation (RUSLE) (Renard et al., 1997), and the Water Erosion Prediction Project (WEPP) model (Nearing et al., 1989) are used to estimate erosion. Soil erodibility parameters are incorporated into both of these models to represent differences in erosion potential which may exist between soils. Selected soil properties have been found to influence soil erodibility factors. The long-term application of manure and fertilizer could affect the soil factors which influence erodibility. In this study, selected soil properties and erodibility factors are determined for a soil on which varying amounts of manure and fertilizer were applied.

\section{RUSLE Model Parameters}

Soil erosion caused by rainfall and its associated overland flow can be estimated using the RUSLE (Renard et al., 1997). A computer program is required to perform computations with RUSLE. RUSLE is used in conservation planning, predicting erosion rates over large areas, and estimating sediment production that might become sediment yield in watersheds. In this study, the soil 
erodibility factor, $\mathrm{K}$, is of particular interest. The susceptibility of soil to erosion, and the amount and rate of runoff are both represented by the $\mathrm{K}$ factor. When the silt fraction does not exceed $70 \%, \mathrm{~K}$ can be calculated from the following equation (Schwab et al., 1993):

$$
\begin{gathered}
\mathrm{K}=2.8 \times 10^{-7} \mathrm{M}^{1.14}(12-\mathrm{a})+4.3 \times 10^{-3}(\mathrm{~b}-2) \\
+3.3 \times 10^{-3}(\mathrm{c}-3)
\end{gathered}
$$

where

$$
\mathrm{M}=(\% \text { silt }+\% \text { very fine sand })(100-\% \text { clay })
$$

and $\mathrm{a}$ is the percent organic matter, $\mathrm{b}$ is the soil structure code, and $\mathrm{c}$ is the profile permeability class. For the Tripp sandy loam soil used in this study, b and c were assigned values of 2 and 3 , respectively.

\section{WePP Model Parameters}

A steady-state sediment continuity equation is used in the WEPP model for predicting sediment transport (Nearing et al., 1989). Detachment, transport, and deposition processes are all represented by the model which is designed to include spatial variability in topography, surface roughness, soil properties, hydrology and land use. An interrill erodibility factor, $\mathrm{K}_{\mathrm{i}}$, rill erodibility factor, $\mathrm{K}_{\mathrm{r}}$, and critical shear stress value, $\tau_{\mathrm{c}}$, must be identified for individual soils to run the model. For cropland soils containing $30 \%$ or more sand (Flanagan and Livingston, 1995):

$$
\begin{gathered}
\mathrm{K}_{\mathrm{i}}=2728000+192100 \times \% \text { very fine sand } \\
\mathrm{K}_{\mathrm{r}}=0.00197+0.00030 \times \% \text { very fine sand } \\
+0.03863 \times \operatorname{EXP}(-1.84 \times \% \text { organic matter }) \\
\tau_{\mathrm{c}}=2.67+0.065 \times \% \text { clay } \\
-0.058 \times \% \text { very fine sand }
\end{gathered}
$$

For cropland soils containing less than $30 \%$ sand:

$$
\begin{gathered}
\mathrm{K}_{\mathrm{i}}=6054000-55130 \times \% \text { clay } \\
\mathrm{K}_{\mathrm{r}}=0.0069+0.134 \times \operatorname{EXP}(-0.20 \times \% \text { clay }) \\
\tau_{\mathrm{c}}=3.5
\end{gathered}
$$

\section{MATERIALS AND METHODS SoIL Characteristics}

This study was conducted on a Tripp (coarse, mixed mesic Typic Haplustolls) sandy loam soil located near Mitchell, NE that was part of a rotation study since 1912. The Tripp series consists of deep, dark chestnut soils located on stream terraces and uplands. These fine granular, moderately permeable soils developed in old alluvium with loess deposits. The sand, silt, and clay content of this soil is 71,26, and 3\%, respectively.

From 1912 to 1941 , one replication of the current longterm study was in continuous corn with no fertilizer or manure application. This replication was split into halves in 1942 with one-half receiving an annual application of cattle feedlot manure (27 $\mathrm{Mg} \mathrm{ha}^{-1}$, w.b.), while no manure was applied to the other half. In 1953, the manure and nomanure plots were split again into six plots $(5.5 \times 12.5 \mathrm{~m}$ each) receiving annual fertilizer applications of $0,45,90$, 135, $180 \mathrm{~kg} \mathrm{~N} \mathrm{ha}^{-1}$, and $135 \mathrm{~kg} \mathrm{~N} \mathrm{ha}^{-1}+80 \mathrm{~kg} \mathrm{P} \mathrm{ha}^{-1}$. A second replication of the manure and fertilizer treatments was established in 1953 on adjacent Tripp soil which had been in a sugarbeet-potato rotation and had received a biennial application of cattle manure (27 $\mathrm{Mg} \mathrm{ha}^{-1}$, w.b.) from 1912 to 1952 . A continuous corn cropping system has been used from 1953 to the present. Several tillage operations occur on this site each year.

Fertilizer and manure were broadcast and disked each year in the spring before planting. Ammonium nitrate was the $\mathrm{N}$ source and triple superphosphate (0-20-0, N-P-K) was the $\mathrm{P}$ source. The area has been furrow irrigated, usually five to seven times each year, depending on crop water needs. Manure has come from the same feedlot, which has had no major changes in manure handling methods in the last 25 years. Selected soil characteristics at the experimental site for various depth increments are reported by Eghball et al. (1996).

A shovel was used to collect soil samples from approximately the top $0.1 \mathrm{~m}$ of the soil profile on 13 April, 1998 before the annual application of manure and fertilizer. Two samples from each of 16 field experimental plots were placed in covered plastic containers, and the resulting 32 containers were then stored until testing.

Samples for soil characterization were obtained before subsequent addition of manure and/or fertilizer from each of the 32 containers using a $1.9 \mathrm{~cm}$ diameter coring device. Individual samples were combined to form a composite sample for each plastic container. Organic matter content and particle-size analysis were determined using procedures outlined by Nelson and Sommers (1982), and Gee and Bauder (1986), respectively.

\section{Manure Characteristics}

The manure used in this study was obtained from the same feedlot near Mitchell, Nebraska, used for the longterm field study. The manure, which had a water content of $37 \%$, was kept in a cooler at $5^{\circ} \mathrm{C}$ until it was added to the soil samples. Manure and/or fertilizer were mixed with the top soil increment at the time of testing for those experimental treatments involving addition of manure and/or fertilizer. The manure had total $\mathrm{N}$ and $\mathrm{P}$ contents of 2.4 and $0.76 \%$ (dry weight basis), respectively. It can be assumed that the plant $\mathrm{N}$ and $\mathrm{P}$ availability of manure in the first year after application was $40 \%$ and $60 \%$, respectively (Eghball and Power, 1999). To produce a corn crop with a target yield of $9.4 \mathrm{Mg} \mathrm{ha}^{-1}$, manure would have to be applied at rates of 15.7 and $5.6 \mathrm{Mg} \mathrm{ha}^{-1}$ (dry mass) to meet $\mathrm{N}$ and $\mathrm{P}$ fertilizer requirements, respectively, assuming no residual effects from previous manure applications. Thus, the $17 \mathrm{Mg} \mathrm{ha}^{-1}$ (d.b.) of manure applied in this study met both plant $\mathrm{N}$ and $\mathrm{P}$ requirements.

\section{EXPERIMENTAL TREATMENTS}

The principal experimental variables used in this study included manure or no-manure application, varying fertilizer application rates, and timing of manure and 
fertilizer applications. The effects of the addition of manure on phosphorus and nitrogen in runoff from interrill areas was examined in a companion study. Results from the nutrient transport investigation will be reported in a subsequent publication.

This study included 16 treatment combinations in a randomized complete block design. The sequence of each treatment was performed randomly and independently for each block. There were two blocks totaling 32 experimental units which included two replications of the following treatments:

Manure applications - 0 and $27 \mathrm{Mg} \mathrm{ha}^{-1}$ (w.b.)

Fertilizer applications $-0 ; 90 ; 180 \mathrm{~kg} \mathrm{~N} \mathrm{ha}^{-1}$; and $135 \mathrm{~kg}$ $\mathrm{N} \mathrm{ha}^{-1}+80 \mathrm{~kg} \mathrm{Pha}^{-1}$

Timing of manure and fertilizer applications - Long-term; and immediately before the rainfall simulation tests

The residual amount of manure and/or fertilizer contained in the soil is at a minimum in the spring prior to the annual addition of manure and/or fertilizer. In contrast, the greatest amounts of manure and/or fertilizer are present immediately after application. Experimental treatments in this study were selected to include both of these conditions.

For the long-term manure and fertilizer applications, rainfall simulation tests were run on 16 soil samples obtained on 13 April 1998. It had been approximately one year since manure and fertilizer were placed on the field plots from which the soil samples were collected. Manure and fertilizer were also added immediately before the rainfall simulation tests to 16 additional soil samples obtained on 13 April 1998. These soil samples represented conditions occurring in the spring immediately after the annual application of manure and fertilizer.

\section{SoIL PAN}

A 1-m, square, stainless steel soil pan which was maintained at a $9 \%$ slope was used in this study. The $9 \%$ slope was arbitrarily selected to provide optimum interrill detachment and transport conditions. A slope adjustment factor for interrill sediment delivery has been reported by Laflen et al. (1991). Three outlets were located on the floor of the 10.2-cm-deep soil pan to provide drainage. To facilitate water movement to the outlets, two wire screens of 6 and $3 \mathrm{~mm}$ mesh, and a cotton fabric were placed on the pan floor before filling with soil (Lattanzi et al., 1974).

The soil pan was constructed without an outside border around its perimeter. Thus, soil could be splashed out of the pan while none was splashed back in resulting in a net splash loss. In this study, it was assumed that the quantity of soil material detached by rainfall impact was much greater than the amount transported by overland flow, making a border area unnecessary (Gilley et al., 1985).

Soil was removed from an individual plastic storage container, large clods were broken by hand, and the soil was then sieved through a 12-mm square hole sieve. The soil was then placed in the soil pan in three successive uniform layers. Each layer was compressed by hand with a wooden block to obtain a uniform bulk density for the manure and no-manure treatments of approximately 1.3 and $1.4 \mathrm{~g} / \mathrm{cm}^{3}$, respectively. These bulk density values had been obtained from field measurements. A fourth layer was applied on the top and leveled without compressing, resulting in a soil sample depth of approximately $7.6 \mathrm{~cm}$. For the experimental tests involving manure and/or fertilizer application, the manure and/or fertilizer were thoroughly mixed with the soil to be used in the fourth layer before it was added to the soil pan. Following individual tests, all of the soil material was removed, the soil pan was cleaned, and additional material from another plastic container was placed in the soil pan for subsequent testing.

\section{RAinfall Simulator}

A rainfall simulator based on a design by Meyer and Harmon (1979) applied rainfall to the soil pan between May and July 1998. An initial 1-h rainfall application at an intensity of approximately $64 \mathrm{~mm} \mathrm{~h}^{-1}$ occurred at existing soil water conditions. A second 1-h application (wet run) was conducted approximately $24 \mathrm{~h}$ later.

A trough extending across the bottom of the plot collected runoff. Runoff samples were obtained at 5-min intervals using collection bottles. The collection bottles were weighed, dried, and reweighed to determine the mass of sediment and water in the bottles. Flow rates and erosion amounts were computed from the mass of water or sediment, sample collection period, and the contributing area.

The runoff samples contained both sediment and manure. Since the quantity of added manure was small when compared to the total amount of soil, the relative quantity of manure in runoff was considered to be minimal (Gilley and Eghball, 1998). Thus, total solids in runoff was reported simply as erosion.

\section{Statistical Analyses}

Duncan's multiple range test was used to determine the effects of the long-term application of manure and fertilizer on runoff and erosion, soil properties, and soil erodibility factors (SAS, 1990). The effects of timing of the most recent manure application on runoff and erosion were also identified. Tests were run at the $10 \%$ probability level.

\section{RESULTS AND DISCUSSION EFFECTS OF THE Long-Term Application of MANURE AND FERTILIZER ON RUNOFF AND EROSION}

No significant differences in total runoff were found between the manure and no-manure treatments during either the initial or wet rainfall simulation runs (table 1). Likewise, total runoff for the various fertilizer treatments was similar during both simulation events. Due to the relatively shallow soil depth and high rainfall intensity, total runoff during the initial and wet rainfall simulation runs was similar ( 47 or $48 \mathrm{~mm}$ ) for the various manure and fertilizer treatments.

During the initial and wet rainfall simulation runs, no significant differences in erosion were found between the manure and no-manure treatments even though there was a trend for less erosion when manure was added. Erosion rates were also similar during the initial or wet rainfall simulation runs for the various fertilizer treatments. Even on those plots where small amounts of fertilizer were used, enough plant material appears to have been produced and added to the soil to cause relatively stable interrill erosion conditions. 
Table 1. Runoff and erosion as affected by the long-term application of manure and fertilizer*

\begin{tabular}{|c|c|c|c|c|}
\hline \multirow[b]{2}{*}{ Experimental Variable } & \multicolumn{2}{|c|}{ Initial Run } & \multicolumn{2}{|c|}{ Wet Run } \\
\hline & $\begin{array}{c}\text { Runoff } \dagger \\
(\mathrm{mm})\end{array}$ & $\begin{array}{l}\text { Erosion } \\
\left(\mathrm{t} \mathrm{ha}^{-1}\right)\end{array}$ & $\begin{array}{c}\text { Runoff } \\
(\mathrm{mm})\end{array}$ & $\begin{array}{l}\text { Erosion } \\
\left(\mathrm{t} \mathrm{ha}^{-1}\right)\end{array}$ \\
\hline \multicolumn{5}{|l|}{ Manure application } \\
\hline 0 & $48 \mathrm{a}$ & $18.6 \mathrm{a}$ & $48 \mathrm{a}$ & $20.5 \mathrm{a}$ \\
\hline 27 t ha $^{-1}$ (w.b.) & $47 \mathrm{a}$ & $16.4 \mathrm{a}$ & $48 \mathrm{a}$ & $18.1 \mathrm{a}$ \\
\hline \multicolumn{5}{|c|}{ Fertilizer application $\left(\mathrm{kg} \mathrm{N} \mathrm{ha}^{-1}\right)$} \\
\hline 0 & $48 \mathrm{a}$ & $16.9 \mathrm{a}$ & $48 \mathrm{a}$ & $19.7 \mathrm{a}$ \\
\hline 90 & $48 \mathrm{a}$ & $17.8 \mathrm{a}$ & $48 \mathrm{a}$ & $19.5 \mathrm{a}$ \\
\hline $135+80 \mathrm{~kg} \mathrm{P} \mathrm{ha}^{-1}$ & $48 \mathrm{a}$ & $17.3 \mathrm{a}$ & $48 \mathrm{a}$ & $18.6 \mathrm{a}$ \\
\hline 180 & $47 \mathrm{a}$ & $17.8 \mathrm{a}$ & $47 \mathrm{a}$ & $19.5 \mathrm{a}$ \\
\hline
\end{tabular}

* Runoff and erosion data are reported for $1 \mathrm{~m}^{2}$ plots where the most recent application of manure and fertilizer was the previous year. Rainfall simulation runs lasted for a 60 -min duration at an average intensity of $64 \mathrm{~mm} \mathrm{~h}^{-1}$.

$\dagger$ Separate statistical analyses were performed for the manure and fertilizer applications, and the initial and wet rainfall simulation runs. For a given manure or fertilizer application and rainfall simulation run, differences in runoff and erosion are significant at the $10 \%$ level (Duncan's multiple range test) if followed by a different letter.

For a given manure or fertilizer application rate, consistently greater amounts of erosion were measured during the wet run. A breakdown of soil aggregates may have occurred during the initial run causing larger erosion rates during the subsequent runs.

The method by which the soil samples were handled in this study could have negatively impacted soil aggregation. Removal of the soil samples from the field, their placement in plastic storage containers, and sieving of the samples through a 12-mm square hole sieve could have reduced soil aggregation compared to the in situ soil condition. As a result, manure induced changes in soil erodibility may have been more evident if the interrill erosion tests had been conducted in the field. However, temporal changes in soil aggregation and interrill erodibility would be expected under field conditions due to frequent tillage, including disking following the application of manure and fertilizer in the spring.

The long-term application of manure to soils with greater amounts of silt and clay may also enhance the quantity and stability of soil aggregates. As a result, greater differences in interrill soil erodibility may be evident between manure and no-manure treatments. Lack of differences in organic matter, very find sand, silt, and clay (table 3) may have contributed to similar erosion measurements on the manure and no-manure treatments. Manure-induced reductions in soil erodibility may also be more pronounced when greater quantities of manure are applied. Additional testing will be required to determine the effects of varying manure application rates on runoff and erosion from other soils.

\section{Runoff and Erosion As AfFected by the Timing of the Most Recent Manure Application}

The addition of manure immediately before a rainfall simulation test to plots on which manure had been applied in previous years did not affect total runoff during the initial rainfall simulation run (table 2). However, slightly more runoff was measured during the second rainfall simulation event (49 vs $48 \mathrm{~mm}$ ) on those plots where manure was applied immediately before the tests. A
Table 2. Runoff and erosion as affected by the timing of the most recent manure application*

\begin{tabular}{|c|c|c|c|c|}
\hline \multirow[b]{2}{*}{$\begin{array}{l}\text { Most Recent } \\
\text { Manure Application }\end{array}$} & \multicolumn{2}{|c|}{ Initial Run } & \multicolumn{2}{|c|}{ Wet Run } \\
\hline & $\begin{array}{l}\text { Runoff } \dagger \\
\text { (mm) }\end{array}$ & $\begin{array}{l}\text { Erosion } \\
\left(\mathrm{t} \mathrm{ha}^{-1}\right)\end{array}$ & $\begin{array}{l}\text { Runoff } \\
(\mathrm{mm})\end{array}$ & $\begin{array}{l}\text { Erosion } \\
\left(\mathrm{t} \mathrm{ha}^{-1}\right)\end{array}$ \\
\hline Previous year & $47 \mathrm{a}$ & $16.4 \mathrm{a}$ & $48 \mathrm{~b}$ & $18.1 \mathrm{a}$ \\
\hline Immediately before test & $47 \mathrm{a}$ & $16.2 \mathrm{a}$ & $49 \mathrm{a}$ & $18.6 \mathrm{a}$ \\
\hline
\end{tabular}

* Runoff and erosion data are reported for $1 \mathrm{~m}^{2}$ plots. Rainfall simulation runs lasted for a 60 -min duration at an average intensity of $64 \mathrm{~mm} \mathrm{~h}^{-1}$.

$\dagger$ Separate statistical analyses were performed for the initial and wet rainfall simulation runs. For a given rainfall simulation run, differences in runoff and erosion are significant at the $10 \%$ level (Duncan's multiple range test) if followed by a different letter.

difference in total runoff of $1 \mathrm{~mm}$ from a total application of $64 \mathrm{~mm}$ is minimal. Thus, it appears that the long-term application of manure had little influence on total runoff.

Similarly, the addition of manure immediately before the rainfall simulation tests to plots on which manure had been applied in previous years did not affect interrill erosion during either the initial or wet rainfall simulation runs. In a previous study, runoff and erosion from simulated rainfall were also unaffected by a single application of manure on plots containing sorghum or wheat residue under either no-till or tillage conditions (Gilley and Eghball, 1998).

\section{EFFects of The Long-Term Application of MANURe and Fertilizer on Selected Soil Properties}

Soil organic matter (an ion exchange material, chelating agent, and buffering material important in soil aggregation) is contained in manure (Eghball and Power, 1994). The addition of beef cattle manure has been found to substantially increase the organic matter content of some soils (Vitosh et al., 1973; Fraser et al., 1988). In this study, organic matter content was greater on those plots where manure was applied (table 3). However, the increase in organic matter was not found to be statistically significant. Organic matter measurements were also similar between fertilizer treatments. Since manure was applied annually at the approximate rate required to meet plant $\mathrm{N}$ requirements, there does not appear to have been a large accumulation of organic matter within the Tripp sandy loam soil.

Table 3. Soil properties resulting from manure and fertilizer applications*

\begin{tabular}{|c|c|c|c|c|}
\hline Experimental Variable & $\begin{array}{c}\text { Organic } \\
\text { Matter } \\
(\%)\end{array}$ & $\begin{array}{c}\text { Very Fine } \\
\text { Sand } \\
(\%)\end{array}$ & $\begin{array}{l}\text { Silt } \\
(\%)\end{array}$ & $\begin{array}{r}\text { Clay } \\
(\%)\end{array}$ \\
\hline \multicolumn{5}{|l|}{ Manure application } \\
\hline 0 & $1.3 \mathrm{a}^{*}$ & $10 \mathrm{a}$ & $25 \mathrm{a}$ & $4 \mathrm{a}$ \\
\hline $27 \mathrm{t} \mathrm{ha}^{-1}$ (w.b.) & $1.8 \mathrm{a}$ & $8 \mathrm{a}$ & $26 \mathrm{a}$ & $2 \mathrm{a}$ \\
\hline \multicolumn{5}{|l|}{$\begin{array}{l}\text { Fertilizer application } \\
\left(\mathrm{kg} \mathrm{N} \mathrm{ha}^{-1}\right)\end{array}$} \\
\hline 0 & $1.5 \mathrm{a}$ & $10 \mathrm{a}$ & $25 \mathrm{a}$ & $3 a$ \\
\hline 90 & $1.5 \mathrm{a}$ & $9 a b$ & $25 \mathrm{a}$ & $2 \mathrm{a}$ \\
\hline $135+80 \mathrm{kP} \mathrm{ha}^{-1}$ & $1.5 \mathrm{a}$ & $8 \mathrm{~b}$ & $26 \mathrm{a}$ & $3 \mathrm{a}$ \\
\hline 180 & $1.6 \mathrm{a}$ & $8 \mathrm{~b}$ & $26 \mathrm{a}$ & $3 \mathrm{a}$ \\
\hline
\end{tabular}

* Separate statistical analyses were performed for the manure and fertilizer applications. For a given manure or fertilizer application, differences in soil properties are significant at the $10 \%$ level (Duncan's multiple range test) if followed by a different letter. 
Some soil material from the feedlot is usually mixed with manure during the manure removal process. Over an extended period of time, soil textural characteristics at the land application site may be affected if sufficient quantities of soil with different textural characteristics are transported from the feedlot along with the manure. Consequently, particle size distribution of soils from the individual plots was measured in this study.

No significant differences in the fractions of very fine sand, silt or clay were found between the manure and nomanure treatments. Thus, the long-term application of manure and associated soil did not appear to affect surface textural characteristics. Primary particle size distribution of soil material on the fertilizer treatments also appeared to be similar, indicating relative uniformity in surface textural characteristics between experimental treatments.

\section{SoIL Erodibility FACTORS RESUlting FROM THE LONG- TERM APPliCATION OF MANURE AND Fertilizer}

It can be seen from equations 1 and 2 that the $\mathrm{K}$ factor used in RUSLE is estimated from the soil's primary particle-size distribution, organic matter content, soil structure, and permeability. Manure induced changes in soil erodibility would most likely be reflected through variations in organic matter content. Particle-size distribution and soil organic matter content were generally unaffected by the long-term application of manure and fertilizer at the rates used in this study. As a result, estimated $\mathrm{K}$ factors were also similar for the various experimental treatments (table 4).

For cropland soils, $\mathrm{K}_{\mathrm{i}}$ is estimated only as a function of the very fine sand (eq. 3) or clay soil fractions (eq. 6). Since the particle-size distribution of the Tripp soil was unaffected by manure application (table 3), equations 3 and 6 are not well-suited for reflecting potential manure induced changes in interrill erodibility. Thus, since only minimal changes in the very fine sand fraction occurred for the Tripp soil (table 3 ), the estimated $\mathrm{K}_{\mathrm{i}}$ values shown in table 4 were similar.

The focus of this article is interrill erodibility. However, by examining the variables found in the equations used to estimate $K_{r}$ and $\tau_{c}$, their suitability in predicting manureinduced changes in erodibility can also be evaluated. Organic matter content is shown to influence $\mathrm{K}_{\mathrm{r}}$ for soils containing $30 \%$ or more sand (eq. 4). The increased organic matter provided by manure application caused a

Table 4. Soil erodibility factors resulting from manure and fertilizer applications*

\begin{tabular}{|c|c|c|c|c|}
\hline Variable & $\begin{array}{c}\mathrm{K} \\
\left(\mathrm{t} \mathrm{ha} \mathrm{h} \mathrm{ha-1} \mathrm{MJ}^{-1}\right. \\
\left.\mathrm{mm}^{-1} \times 10^{2}\right)\end{array}$ & $\begin{array}{l}\mathrm{K}_{\mathrm{i}} \\
\left(\mathrm{kg} \mathrm{s}^{-1} \mathrm{~m}^{-4}\right. \\
\left.\times 10^{-6}\right)\end{array}$ & $\begin{array}{l}\mathrm{K}_{\mathrm{r}} \\
\left(\mathrm{s} \mathrm{\textrm {m } ^ { - 1 }}\right. \\
\left.\times 10^{3}\right)\end{array}$ & $\begin{array}{c}\tau_{\mathrm{c}} \\
\text { (Pascals) }\end{array}$ \\
\hline \multicolumn{5}{|l|}{ Manure application } \\
\hline 0 & $3.5 \mathrm{a}$ & $4.63 \mathrm{a}$ & $8.79 \mathrm{a}$ & $2.35 \mathrm{a}$ \\
\hline $27 \mathrm{t} \mathrm{ha}^{-1}$ (w.b.) & $3.3 \mathrm{a}$ & $4.24 \mathrm{a}$ & $6.09 \mathrm{a}$ & $2.35 \mathrm{a}$ \\
\hline \multicolumn{5}{|l|}{$\begin{array}{l}\text { Fertilizer application } \\
\left(\mathrm{kg} \mathrm{N} \mathrm{ha}^{-1}\right)\end{array}$} \\
\hline 0 & $3.5 \mathrm{a}$ & $4.69 \mathrm{a}$ & $8.23 \mathrm{a}$ & $2.29 \mathrm{a}$ \\
\hline 90 & $3.5 \mathrm{a}$ & $4.44 \mathrm{ab}$ & $7.34 \mathrm{ab}$ & $2.31 \mathrm{a}$ \\
\hline $135+80 \mathrm{k} \mathrm{P} \mathrm{ha}^{-1}$ & $3.4 \mathrm{a}$ & $4.33 \mathrm{ab}$ & $7.30 \mathrm{ab}$ & $2.40 \mathrm{a}$ \\
\hline 180 & $3.4 \mathrm{a}$ & $4.26 \mathrm{~b}$ & $6.90 \mathrm{~b}$ & $2.39 \mathrm{a}$ \\
\hline
\end{tabular}

* For a given manure or fertilizer application, differences in soil erodibility factors are significant at the $10 \%$ level (Duncan's multiple range test) if followed by a different letter. reduction in the estimated $\mathrm{K}_{\mathrm{r}}$ value (table 4), but the decrease was not statistically significant. The organic matter content of soils used for land application could provide an indirect estimate of the effects of manure addition on $\mathrm{K}_{\mathrm{r}}$. For cropland soils containing less than $30 \%$ sand, $\mathrm{K}_{\mathrm{r}}$ is a function only of clay content (eq. 7).

The fractions of clay and very fine sand are used to estimate $\tau_{c}$ for cropland soils containing more than $30 \%$ sand (eq. 5). For soils with less than $30 \%$ sand, $\tau_{\mathrm{c}}$ is a constant (eq. 8). Thus, manure-induced changes in $\tau_{c}$ can not be easily reflected using the present form of the predictive equations.

\section{CONCLUSIONS}

Simulated rainfall of $64 \mathrm{~mm} \mathrm{~h}^{-1}$ was applied during initial and wet runs to a $1 \mathrm{~m}^{2}$ soil pan containing a Tripp sandy loam soil obtained from a site near Mitchell, NE. The soil samples used in this investigation had received manure (27 $\mathrm{Mg} \mathrm{ha}^{-1}$ w.b.) and varying rates of fertilizer for 55 years. The long-term application of manure and/or fertilizer did not significantly affect runoff and erosion during either rainfall simulation event. Runoff and erosion were also generally unaffected by the addition of manure immediately before the rainfall simulation tests to soils on which manure had been applied in previous years. In general, the addition of manure and fertilizer did not significantly affect soil organic matter, selected soil properties, or estimated soil erodibility factors.

Additional testing is necessary to determine the effects of varying manure application rates on runoff and erosion for other soils. The soil properties influenced by manure application must also be identified and their impact on soil erodibility determined. Finally, some of the equations currently used to estimate soil erodibility must be modified, if manure-induced changes in erodibility are to be accurately represented.

\section{REFERENCES}

Chandra, S., and S. K. De. 1982. Effect of cattle manure on soil erosion by water. Soil Sci. 133: 228-231.

Eghball, B., and J. F. Power. 1994. Beef cattle manure management. J. Soil Water Conserv. 49(2): 113-122.

Eghball, B., G. D. Binford, and D. D. Baltensperger. 1996. Phosphorus movement and adsorption in a soil receiving longterm manure and fertilizer application. J. Environ. Qual. 25(6): 1339-1343.

Eghball, B., and J. F. Power. 1999. Phosphorus and nitrogen-based manure and compost application: Corn production and soil phosphorus. Soil Sci. Soc. Am. J. 63(4): In Press.

Flanagan, D. C., and S. J. Livingston. 1995. WEPP User Summary. NSERL Report No. 11. West Lafayette, Ind.: National Soil Erosion Research Laboratory, USDA-Agric. Res. Service.

Fraser, D. G., J. W. Doran, W. W. Sahs, and G. W. Lesoing. 1988. Soil microbial populations and activities under conventional and organic management. J. Environ. Qual. 17(4): 585-590.

Gee, G. W., and J. W. Bauder. 1986. 2nd Ed. Particle-size analysis. In Methods of Soil Analysis. Part 1. Physical and Mineralogical Methods, 383-411, eds. A. Klute et al. Madison, Wis.: American Society of Agronomy.

Giddens, J., and A. P. Barnett. 1980. Soil loss and microbiological quality of runoff from land treated with poultry litter. $J$. Environ. Qual. 9(3): 518-520. 
Gilley, J. E., D. A. Woolhiser, and D. B. McWhorter. 1985. Interrill soil erosion-Part II: Testing and use of model equations. Transactions of the ASAE 28(1): 154-159.

Gilley, J. E., and B. Eghball. 1998. Runoff and erosion following field application of beef cattle manure and compost. Transactions of the ASAE 41(5): 1289-1294.

Laflen, J. M., W. J. Elliot, J. R. Simanton, C. S. Holzhey, and K. D. Kohl. 1991. WEPP soil erodibility experiments for rangeland and cropland soils. J. Soil \& Water Cons. 46(1): 39-44.

Lattanzi, A. R., L. D. Meyer, and M. F. Baumgardner. 1974. Influences of mulch rate and slope steepness on interrill erosion. Soil Sci. Soc. Am. J. 38(6): 946-950.

Meyer, L. D., and W. C. Harmon. 1979. Multi-intensity rainfall simulator for erosion research on row side slopes. Transactions of the ASAE 22(1): 100-103.

Mitchell, J. K., and R. W. Gunther. 1976. The effects of manure applications on runoff, erosion and nitrate losses. Transactions of the ASAE 19(6): 1104-1106.

Mueller, D. H., R. C. Wendt, and T. C. Daniel. 1984. Soil and water losses as affected by tillage and manure application. Soil Sci. Soc. Am. J. 48(4): 896-900.

Nearing, M. A., G. R. Foster, L. J. Lane, and S. C. Finkner. 1989. A process-based soil erosion model for USDA-water erosion prediction technology. Transactions of the ASAE 32(5): 15871593.
Nelson, D. W., and L. E. Sommers. 1982. 2nd Ed. Total C, organic C, and organic matter. In Methods of Soil Analysis. Part 2. Chemical and Microbiological Properties, 539-579, eds. A. L. Page et al. Madison, Wis.: American Society of Agronomy.

Renard, K. G., G. R. Foster, G. A. Weesies, D. K. McCool, and D. C. Yoder, Coordinators. 1997. Predicting Soil Erosion by Water: A Guide to Conservation Planning with the Revised Soil Loss Equation (RUSLE). U.S. Department of Agriculture, Agriculture Handbook 703. Washington, D.C.: GPO.

SAS Institute. 1990. 4th Ed. SAS/STAT User's Guide, Ver. 6.0, Vol. 2. Cary, N.C.: SAS Inst.

Schwab, G. O., D. D. Fangmeier, W. J. Elliot, and R. K. Frevert. 1993. 4th Ed. Soil and Water Conservation Engineering. Singapore: John Wiley \& Sons.

Vitosh, M. L., J. F. Davis, and B. D. Knezek. 1973. Long-term effects of manure, fertilizer, and plow depth on chemical properties of soils and nutrient movement in a monoculture corn system. J. Environ. Qual. 2(2): 296-299.

Westerman, P. W., T. L. Donnelly, and M. R. Overcash. 1983. Erosion of soil and poultry manure-A laboratory study. Transactions of the ASAE 26(4): 1070-1078, 1084. 